\title{
Investigation of influence of pre-treatment and low-temperature on drying kinetics, sorption properties, shrinkage and color of brown seaweeds (Saccharina Latissima)
}

\section{Tolstorebrov, I. ${ }^{\text {**}}$; Eikevik, T.M. ${ }^{\text {a }}$ Petrova, I. ${ }^{\text {a }}$; Shokina, Y. ${ }^{\text {b; Bantle, M. }}$ c $^{c}$}

a Department of Energy and Process Engineering, Norwegian University of Science and Technology, NO-7049 Trondheim, Norway

Tel.: +47 73593742,

b Department of Food Production Technology, Murmansk State Technical University, Murmansk Russian Federation

c Sintef Energy Research, Trondheim Norway

*E-mail of the corresponding author: ignat.tolstorebrov@ntnu.no

\begin{abstract}
Drying kinetics of Saccharina latissima (raw and blanched) at low temperatures $\left(10.0,25.0\right.$ and $\left.38.0^{\circ} \mathrm{C}\right)$ was studied. The effective moisture diffusivity coefficient varied due to temperature alterations in the range between 1.4 and $4.510^{-10} \mathrm{~m}^{2} / \mathrm{s}$ for raw and 0.91 and $2.5610^{-10} \mathrm{~m}^{2} / \mathrm{s}$ for blanched seaweeds. Significant changes in structural properties and chemical composition resulted in a much longer drying time of blanched seaweeds, when compared with raw. Drying temperature of $38.0^{\circ} \mathrm{C}$ resulted in more brown color, when compared with other samples. Sorption characteristics of dried raw seaweeds depended on salt content and showed high accumulation of moisture at relative humidity of air of $80.0 \%$. The blanched seaweeds showed linear accumulation of moisture within increasing of relative humidity of drying air from 20.0 to $80.0 \%$, but high level of hysteresis was determined between sorption and desorption isotherms. The shrinkage development within dewatering of blanched and raw samples was also studied.
\end{abstract}

Keywords: brown seaweeds, drying kinetics, sorption isotherms, color 


\section{Introduction}

As much as $36 \%$ (30 million tons of total harvest) of seaweed is used as a direct food source $^{[1]}$. The main representatives of the food-grade seaweeds are: Laminaria japonica (Kombu) and Saccharina latissima (Royal Kombu) ${ }^{[2]}$, which are mostly produced and consumed inAsia. At the same time the key advantage (and the main potential) of the seaweed industry in Europe is its independence from three main resources, that limit conventional agriculture: land, water and fertilizers ${ }^{[3]}$. The brown seaweeds Saccharina Latissima are cultivated now in Norway with the aim to produce food-grade products. However, the harvesting season is short and raw material has a very low stability. Thus, the effective stabilization method is required.

Drying is the common way to preserve food products like seaweed and most of the seaweeds are sold in a dried form ${ }^{[4]}$. Solar and natural drying of seaweeds is a costeffective method. At the same time climate conditions can result in a high final moisture content in dried porduct ${ }^{[5]}$ due to high moisture absorption ability ${ }^{[6]}$, aslo, the process 5 or 7 days ${ }^{[7]}$ and this is not a feasible and safe to apply the method for food graded seaweeds for European market. The demand for traceability and safety appears, when the drying process is used for food production. Drying of seaweeds for long time and/or at high temperature influences negatively on their carbohydrates, amino acid composition and vitamin content ${ }^{[8]}$. The resent study of Saccharina Latissima revealed that decreasing of the drying temperatures results in the increasing of quality ${ }^{[9]}$

The task of this study was the determination of the main process dependencies for the low temperature drying of Saccharina Latissima after frozen storage with the aim of implementation this knowledge into the sustainable drying process.

\section{Materials and Methods}

\subsection{Characterization of raw material}

The brown algae Saccharina latissima, which is commonly referred as kelp (Sugar kelp or kombu) was used for the experiments. The seaweeds was cultivated for one year in an aquaculture farm, which is situated in Sør-Trøndelag (Norway). Harvesting season was 3 days in May 2016 to maintain the best quality of the seaweeds and avoid high amount of biofouling. The seaweed was harvested into nets $(75-150 \mathrm{~kg})$. The nets were buffered in the seawater at the farm for up to 1 weeks before processing. Then the seaweeds were sorted to remove seaweed of a bad quality. Afterwards, the seaweed was weighed out and packed inside vacuum bags with high barrier properties ( $2.0 \mathrm{~kg}$ each). Freezing was at $-46{ }^{\circ} \mathrm{C}$ for 20-25 min until the temperature inside the bag reached $-18.0^{\circ} \mathrm{C}$. The bags were packed in cardboard boxes, put on pallets and placed in freeze storage at $-18{ }^{\circ} \mathrm{C}$. The freezing process was applied to stabilize the product, because harvesting season is short (few days) and high 
amount of biomass is difficult to process before deterioration will start. Chemical composition of the aquaculture seaweeds is given in the Table 1.

Table 1. Chemical composition of Saccharina latissima at harvesting season (analysis performed by accredited analytical laboratory Kystlab preBIO, Frøya, Norway).

\begin{tabular}{|c|c|c|c|}
\hline Chemical composition & $\%, d . b$. & Minerals, $\mathrm{mg} / \mathrm{kg}$ d.b. & \\
\hline Proteins & 11.2 & Potassium & 84000 \\
\hline Fats & 2.9 & Sodium & 52000 \\
\hline Carbohydrates & 55.3 & Calcium & 10000 \\
\hline Incl. Dietary fiber & 46.6 & Magnesium & 7500 \\
\hline Ash & 37.9 & Sulfur & 7300 \\
\hline Incl. Salt $(\mathrm{NaCl})$ & 14.6 & Iodine & 3670 \\
\hline Water & 900.0 & Phosphrus & 1700 \\
\hline
\end{tabular}

\subsection{Experiment description}

The frozen seaweeds were divided into two groups: one was blanched seaweeds another group was raw seaweeds without any processing. Frozen seaweeds were defrosted at +5.0 ${ }^{\circ} \mathrm{C}$ in refrigeration cabin to avoid significant degradation of tissues. The blanching took place in a boiling water $\left(100.0^{\circ} \mathrm{C}\right)$ for $1.0 \mathrm{~min}$. The balnched seaweeds were immediately cooled in water $\left(5.0^{\circ} \mathrm{C}\right)$. The drying took place on shelves in drying chamber with a closed loop air circulation. The following parameters were varied during drying experiments: air temperature: 10, 25 and $38{ }^{\circ} \mathrm{C}$; amount of seaweed's layers: 1 layer, 2 and 3. The seaweeds were placed in a drying chamber on shelves parallel to the air flow. Relative humidity of drying air for all cases was $16.0 \pm 4.0 \%$. Drying air velocity $1.5 \pm 0.5 \mathrm{~m} / \mathrm{s}$. The drying process was stopped when the moisture content was in the range between 20.0 and $10.0 \%$ d.b.

\subsection{Determination of drying kinetics}

The drying behaviors were modelled using Newton model. The drying behavior itself was charactericed via determination of the effective moisture diffusivity. This material property was derived from the drying kinetics via analytical solution of the Fick's second law of diffusion (infinite slab).

\subsection{Determination of sorption and desorption properties at different temperatures}

Sorption isotherms were determined for dried balnched and dried raw seaweeds at 10.0, 25.0 and $38.0{ }^{\circ} \mathrm{C}$. Desorption properties were determined by drying of raw seaweeds at 25.0 ${ }^{\circ} \mathrm{C} 20.0 \% \mathrm{RH}$. 


\subsection{Determination of color}

Color was analyzed with the assistance of ColorFlex EZ Spectrophotometer (HunterLab, USA) using CIE $\mathrm{L}^{*} \mathrm{C}^{*} \mathrm{~h} *$ scale. The lightness $\mathrm{L}^{*}$ varies from black $\left(\mathrm{L}^{*}=0\right)$ to perfect white $\left(L^{*}=100\right)$. The chromaticity $C^{*}$ reflects the colorfulness; when $C^{*}=0$, the object is considered to be colorless. Hue is an attribute of a visual sensation, according to which an area appears be similar to one of the perceived colours or to a combination of two of them. It is measured in degrees from 0 to $360^{\circ}$, rose $\left(h^{*}=0^{\circ}\right)$, yellow $\left(h^{*}=90^{\circ}\right)$, green-blue $\left(\mathrm{h}^{*}=180^{\circ}\right)$, and blue-violet $\left(\mathrm{h}^{*}=270^{\circ}\right)$.

\subsection{Statistical analysis}

The analysis of variance (ANOVA: single test and two-factor test with replication) was applied to analyze the obtained data. The difference was considered significant at $\mathrm{p}<0.05$. All the experimental points were done in six parallels, except of desorption isotherm determination, where each point represents a single experiment. A regression analysis was done with a software DataFit 8.1 program (Oakdale Engineering).

\section{Results and Discussion}

\subsection{Influence of pretreatment and drying modes on color of seaweeds}

The blanching process alternated the lightness $\left(\mathrm{L}^{*}\right)$, chrominance $(\mathrm{C})$, and hue $(\mathrm{h})$ of the seaweeds $(\mathrm{p}<0.05)$. The typical brown-olive color (by human eye perception) of the seaweeds visually changed to green, this was reflected by increasing of hue by $12^{\circ}$ and alteration of chrominance by $71.0 \%$, Table 2. The lightness of dried raw samples were significantly higher when compared with dried blanched $(\mathrm{p}<0.05)$. This might be possible due to deposits of salts and other water soluble compounds (for example, mannitol) on the surface of the dried blades of Saccharina latissima, which created a layer on surface with high reflective properties. Chrominance of dried raw seaweeds was also higher $(\mathrm{p}<0.05)$. Some interesting observations were found regarding the influence of temperature on the hue-value of the dried seaweeds. The drying temperature of $38.0{ }^{\circ} \mathrm{C}$ resulted in a slight decreasing of the hue-value, so the color became more "orange (brown)" (in terms of $\mathrm{L} * \mathrm{C} * \mathrm{~h} *$ color space), while the seaweeds dried at $10.0{ }^{\circ} \mathrm{C}$ showed more "yellow-green" color. This was valid both for raw and blanched seaweeds. One of the possible explanation may be a higher oxidation rate of the pigments by oxygen at a higher temperatures ${ }^{[10]}$. 
Table 2. Color parameters of raw and blanched seaweeds before and after drying

\begin{tabular}{|c|c|c|c|c|c|c|c|c|c|}
\hline \multirow{2}{*}{$\begin{array}{l}\text { Type of } \\
\text { seaweeds }\end{array}$} & \multicolumn{9}{|c|}{ Before drying (Color parameters) } \\
\hline & \multicolumn{2}{|c|}{$L^{*},(-)$} & \multicolumn{2}{|l|}{ C, (-) } & h, ${ }^{o}$ & \multicolumn{2}{|c|}{$a^{*},(-)$} & \multicolumn{2}{|c|}{$\mathbf{b}^{*},(-)$} \\
\hline $\begin{array}{c}\text { Raw } \\
\text { seaweeds }\end{array}$ & \multicolumn{2}{|c|}{9.78} & \multicolumn{2}{|c|}{$\begin{array}{c}8.08 \\
(1.97)\end{array}$} & $\begin{array}{l}80.23 \\
(1.45)\end{array}$ & \multicolumn{2}{|c|}{1.39} & \multicolumn{2}{|c|}{7.96} \\
\hline $\begin{array}{l}\text { Blanched } \\
\text { seaweeds }\end{array}$ & \multicolumn{2}{|c|}{$\begin{array}{l}11.54 \\
(1.29)\end{array}$} & \multicolumn{2}{|l|}{$\begin{array}{l}13.84 \\
(1.63)\end{array}$} & $\begin{array}{l}92.00 \\
(4.04)\end{array}$ & \multicolumn{2}{|c|}{$\begin{array}{l}-0.13 \\
(1.25)\end{array}$} & \multicolumn{2}{|c|}{$\begin{array}{l}14.74 \\
(1.39)\end{array}$} \\
\hline \multicolumn{10}{|c|}{ After drying (Color parameters) } \\
\hline & \multicolumn{2}{|c|}{$L^{*},(-)$} & \multirow[t]{2}{*}{$\mathrm{C},(-)$} & \multirow{2}{*}{\multicolumn{4}{|c|}{ Temperature, ${ }^{\circ} \mathrm{C}$}} & & \\
\hline & & & & & & & & & \\
\hline \multirow{3}{*}{$\begin{array}{l}\text { Blanched } \\
\text { seaweeds }\end{array}$} & 38.0 & 25.0 & 10.0 & 38.0 & 25.0 & 10.0 & 38.0 & 25.0 & 10.0 \\
\hline & $23.1^{\mathrm{a}}$ & $23.7^{\mathrm{a}}$ & $23.83^{\mathrm{a}}$ & $6.4^{\mathrm{c}}$ & $5.76^{\mathrm{c}}$ & $6.59^{c}$ & $81.39^{e}$ & $82.85^{\mathrm{e}}$ & $86.86^{f}$ \\
\hline & $(1.54)$ & (2.19) & $(1.23)$ & $(2.84)$ & (1.89) & $(1.32)$ & $(5.66)$ & $(4.57)$ & (3.3) \\
\hline \multirow{2}{*}{$\begin{array}{c}\text { Raw } \\
\text { seaweeds }\end{array}$} & $25.86^{\mathrm{b}}$ & $27.25^{\mathrm{b}}$ & 27.91 & $8.71^{\mathrm{d}}$ & $8.39^{\mathrm{d}}$ & $8.42^{\mathrm{d}}$ & $83.39^{\mathrm{e}}$ & $86.00^{f}$ & $86.73^{f}$ \\
\hline & $(1.12)$ & $(2.78)$ & $(2.46)$ & (1.33) & $(1.02)$ & (1.09) & (3.07) & $(2.53)$ & (3.03) \\
\hline
\end{tabular}

\subsection{Sorption-desorption characteristics of Saccharina latissima}

The dried raw and blanched seaweeds behave differently during absorption of moisture from the ambient air (Fig. 1). Dried blanched seaweeds showed higher accumulation of moisture at low relative humidity of air (from 20.0 to $40.0 \% \mathrm{RH}$ ) for all the investigated samples, when compared with raw seaweeds $(\mathrm{p}<0.05)$. While, the trend was changed at $60.0 \% \mathrm{RH}$. Further increasing of the relative humidity in the climate chamber to $80.0 \%$ resulted in a sharp alteration of moisture content in dried raw seaweeds for all the investigated temperatures $(\mathrm{p}<0.05)$, while dried blanched seaweeds showed almost linear trend of moisture increasing in the range of $\mathrm{RH}$ between 20.0 and $80.0 \%$. The temperature variation between 10.0 and $38.0{ }^{\circ} \mathrm{C}$ did not influence on the sorption characteristic of the blanched seaweeds.

The similar behavior was observed by Sappati et al., ${ }^{[11]}$ studied the sorption isotherms of Saccharina latissima at $20.0^{\circ} \mathrm{C}$. The sharp increasing of the equilibrium moisture content of raw seaweeds at $80.0 \%$ and relatively low water absorbance at RH below $60.0 \%$ can be explained by hygroscopic point of salts, which occupy the significant share among other compounds. For example, hygroscopic point of $\mathrm{NaCl}$ appears at $75.5 \% \mathrm{RH}$ at $25.0{ }^{\circ} \mathrm{C}, \mathrm{KCl}$ at $82.0 \% \mathrm{RH}$. The salt concentration in raw seaweeds was determined at $14.4 \%$ d.b., while blanched seaweeds were almost salt-free (below $0.5 \%$ d.b). Desorption isotherms were determined at $25.0{ }^{\circ} \mathrm{C}$ and compared with sorption profiles at the same temperature. It is interesting to note, that hysteresis phenomena was relatively small for raw seaweeds, while blanched seaweeds showed a significant change in structural properties during drying. It may happens due to freezing and blanching process when the cell membranes were broken and water soluble compounds were easily washed out and replaced by a free water. Thus, significant irreversible shrinkage appears during drying process of blanched seaweeds. 


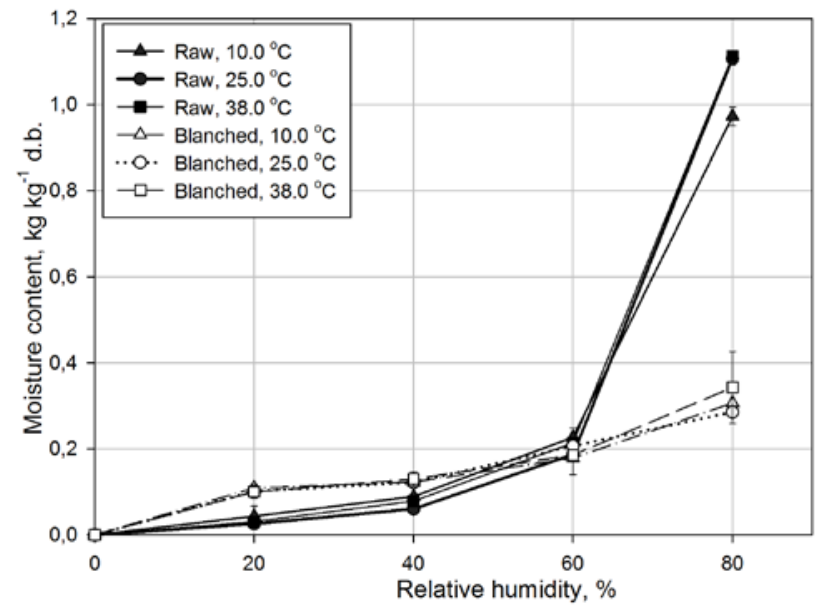

Figure 1. Sorption characteristics of Saccharina Latissima

\subsection{Shrinkage of raw and blanched seaweeds during dewatering}

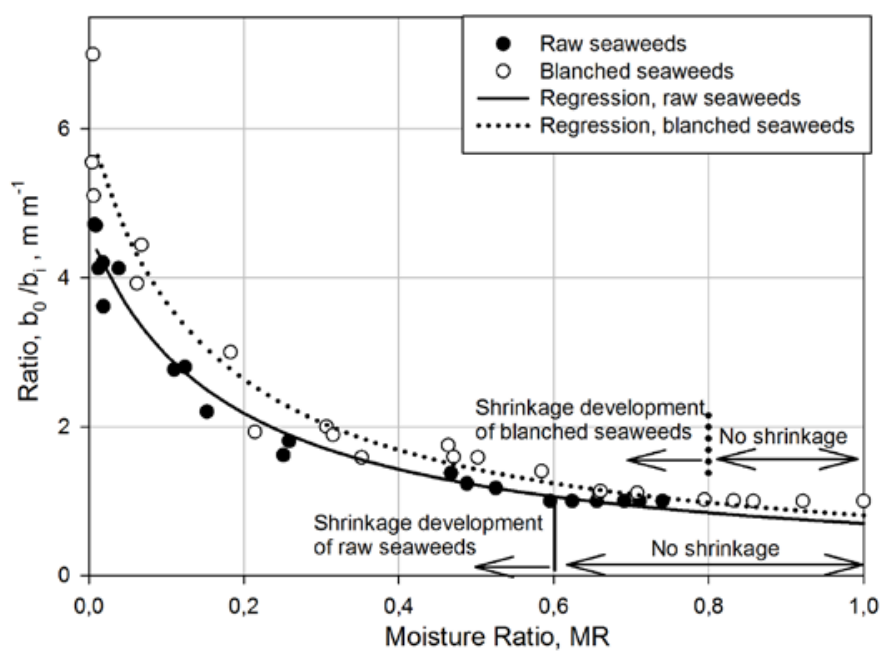

Figure 2. Shrinkage of raw and blanched seaweeds during drying

The drying processes resulted in a significant reduction of blade thickness for raw and blanched seaweeds, Fig. 2, while surface area reduced only by 20.0..25.0\%.

The thickness reductions was much more developed for blanched blades, when compared with raw samples $(\mathrm{p}<0.05)$. Also, raw seaweeds retained their thickness much longer during 
dewatering when compared with blanched. The first traces of the thickness decreasing were detected at MR of 0.6 and 0.8 at $25.0^{\circ} \mathrm{C}$ for raw and blanched seaweeds respectively.

\subsection{Drying kinetics of seaweeds}

The drying kinetics was investigated for raw and blanched seaweeds. The raw seaweeds showed initial moisture content at 900.0 (50.0) \% d.b. Tthe moisture content of the blanched seaweeds was found at 2079.0 (100.0) \% d.b. Dehydration of raw seaweeds was much faster, when compared with blanched. This can be explained by the higher moisture content of blanched seaweeds and also may be linked with the changes of their structure after blanching. The increasing of temperature accelerated the dewatering of the seaweeds both raw and blanched, and the highest dewatering rate was observed for $38.0^{\circ} \mathrm{C}$.

Newton model was implemented to obtain the regression equations for all the drying temperatures $\left(\mathrm{R}^{2}>0.98 ; \operatorname{Prob}(\mathrm{F})<0.000014 ; \mathrm{F}\right.$ (Ratio) $\left.>700\right)$. The empirical drying coefficient $\mathrm{k}$ was found in the range between 0.008 and $0.221 / \mathrm{min}$ due to the influence of temperature and variation of thickness of the sample.

Table 3. Coefficients for Newton equation and effective moisture diffusivity

\begin{tabular}{|c|c|c|c|c|c|}
\hline \multirow{2}{*}{$\begin{array}{c}\text { Type of } \\
\text { seaweeds }\end{array}$} & \multirow{2}{*}{$\begin{array}{l}\text { Drying } \\
\text { temp., } \\
{ }^{\circ} \mathrm{C}\end{array}$} & \multicolumn{4}{|c|}{ Drying coefficient, $1 / \mathrm{min}$} \\
\hline & & 1 layer & & 2 layers & 3 layers \\
\hline \multirow{3}{*}{ Raw seaweeds } & 10.0 & $0.07(0.01)$ & & $0.015(0.01)$ & $0.016(0.001)$ \\
\hline & 25.0 & $0.13(0.01)$ & & $0.033(0.01)$ & $0.021(0.001)$ \\
\hline & 38.0 & $0.22(0.01)$ & & $0.055(0.01)$ & $0.036(0.001$ \\
\hline \multirow{5}{*}{ Blanched } & 10.0 & $0.035(0.001)$ & & $.017(0.002)$ & $0.008(0.002)$ \\
\hline & 25.0 & $0.051(0.001)$ & & $.025(0.003)$ & $0.013(0.002)$ \\
\hline & 38.0 & $0.060(0.001)$ & & $.031(0.004)$ & $0.015(0.001)$ \\
\hline & & \multicolumn{3}{|c|}{ Effective diffusivity, $\mathrm{D} \mathrm{m}^{2} / \mathrm{s}^{*} 10^{10}$} & Average \\
\hline & & 1 layer & 2 layers & 3 layer & \\
\hline \multirow{3}{*}{ Raw seaweeds } & 10.0 & 1.50 & 1.20 & 1.50 & $1.4(0.17)$ \\
\hline & 25.0 & 2.80 & 2.60 & 2.60 & $2.7(0.11)$ \\
\hline & 38.0 & 4.50 & 4.00 & 5.00 & $4.50(0.5)$ \\
\hline \multirow{3}{*}{$\begin{array}{l}\text { Blanched } \\
\text { seaweeds }\end{array}$} & 10.0 & 0.95 & 0.90 & 0.90 & $0.91(0.03)$ \\
\hline & 25.0 & 1.10 & 1.50 & 1.10 & $1.2(0.23)$ \\
\hline & 38.0 & 2.50 & 2.60 & 2.60 & $2.56(0.05)$ \\
\hline
\end{tabular}

The average values of effective moisture diffusivity (Table 3) increased with increasing of the drying temperature and reached the highest value of $3.5^{*} 10^{-10} \mathrm{~m}^{2} / \mathrm{s}$ at $38.0{ }^{\circ} \mathrm{C}$. The effective moisture diffusivities of blanched seaweeds were relatively lower, when compared with raw seaweeds. The results of this study were in agreement with the resent study on Saccharina latissima ${ }^{[11]}$, when the effective moisture diffusivity was determined at $2.95^{*} 10^{-}$ ${ }^{10} \mathrm{~m}^{2} / \mathrm{s}$ at $40.0^{\circ} \mathrm{C}$ and $25.0 \%$ RH. 
Investigation of influence of pre-treatment and low-temperature on drying kinetics, sorption properties, shrinkage and color of brown seaweeds (Saccharina Latissima)

\section{Conclusions}

Drying kinetics of Saccharina latissima (raw and blanched) at low temperatures (10.0, 25.0 and $38.0{ }^{\circ} \mathrm{C}$ ) was studied. The effective moisture diffusivity coefficient varied due to temperature alterations in the range between 1.4 and $4.510^{-10} \mathrm{~m}^{2} / \mathrm{s}$ for raw and 0.91 and $2.5610^{-10} \mathrm{~m}^{2} / \mathrm{s}$ for blanched seaweeds. Significant changes in structural properties and chemical composition resulted in a much longer drying time of blanched seaweeds, when compared with raw. Drying temperature of $38.0{ }^{\circ} \mathrm{C}$ resulted in more brown color, when compared with other samples. Sorption characteristics of dried raw seaweeds depended on salt content and showed high accumulation of moisture at relative humidity of air of 80.0 $\%$. The blanched seaweeds showed linear accumulation of moisture within increasing of relative humidity of drying air from 20.0 to $80.0 \%$, but high level of hysteresis was determined between sorption and desorption isotherms. The shrinkage development within dewatering of blanched and raw samples was also studied.

\section{Asknowledgement}

Mobility of the scientists from Murmansk State Technical University was provided by financial support of SIU, High North Programme 2015 (HNP-2015/10053)

\section{References}

[1] FAO The state of world fisheries and aquaculture: opportunities and challenges. 2014, Rome: FAO.

[2] Chopin, T. Seaweed aquaculture provides diversified products, key ecosystem functions Part II. Recent evolution of seaweed industry. Kye acosyst. Func. 2012, 14, p. 24-27.

[3] Radulovich, R. Massive freshwater gains from producing food at sea. Water Policy 2011, 13(4), p. 547.

[4] Forster, J.; Radulovich, R. Chapter 11 - Seaweed and food security A2 - Tiwari, Brijesh K, in Seaweed Sustainability; D.J. Troy, Editor; Academic Press: San Diego, 2015

[5] Phang, H.-K.; Chu, C.-M.; Kumaresan, S.; Rahman, M.M.; Yasir, S.M. Preliminary study of seaweed drying under a shade and in a natural draft solar dryer. International Journal of Science and Engineering 2015, 8(1), p. 10-14.

[6] Lemus, R.A.; Pérez, M.; Andrés, A.; Roco, T.; Tello, C.M.; Vega, A. Kinetic study of dehydration and desorption isotherms of red alga Gracilaria. LWT - Food Science and Technology 2008, 41(9), p. 1592-1599.

[7] Fudholi, A.; Othman, M.Y.; Ruslan, M.H.; Yahya, M.; Zaharim, A.; Sopian, K. Design and testing of solar dryer for drying kinetics of seaweed in Malaysia, in Proceedings of the 4th WSEAS international conference on Energy and development - environment - biomedicine. 2011, World Scientific and Engineering Academy and Society (WSEAS): Corfu Island, Greece. p. 119-124.

[8] Chan, J.C.C.; Cheung, P.C.K.; Ang, P.O. Comparative Studies on the Effect of Three Drying Methods on the Nutritional Composition of Seaweed Sargassum hemiphyllum (Turn.) C. Ag. Journal of Agricultural and Food Chemistry 1997, 45(8), p. 3056-3059.

[9] Stévant, P.; Indergård, E.; Ólafsdóttir, A.; Marfaing, H.; Larssen, W.E.; Fleurence, J.; Roleda, M.Y.; Rustad, T.; Slizyte, R.; Nordtvedt, T.S. Effects of drying on the nutrient content and physico-chemical and sensory characteristics of the edible kelp Saccharina latissima. Journal of Applied Phycology 2018.

[10]Mise, T.; Ueda, M.; Yasumoto, T. Production of fucoxanthin-rich powder from Cladosiphon Okamuranus. Advance Journal of Food Science and Technology 2011, 3(1), p. 73-76.

[11]Sappati, P.K.; Nayak, B.; van Walsum, G.P. Effect of glass transition on the shrinkage of sugar kelp (Saccharina latissima) during hot air convective drying. Journal of Food Engineering 2017, 210, p. 50-61. 